\title{
Growth performance of wild strains of Clarias gariepinus from Nigerian waters
}

\author{
Megbowon, I. / Fashina-Bombata, H. A. / Akinwale, M. M-A. / \\ Hammed, A. M. / Mojekwu, T. O. / Okunade, O. A./ Shell, R. O. D.
}

\begin{abstract}
The catfish (Clarias gariepinus) is the leading aquatic crop in Nigeria. Most of the strains used in aquacuiture are suffering from inbreeding depression with its attendant poor egg and sperm quality. There is therefore the need to explore the natural population of the fish to improve performance. This study was carried out to evaluate the growth performance of strains of the catfish across the freshwater systems of Nigeria. Collections were made from the six geopolitical zones namely: North-Ceniral (Kogi), Northeast (Adamawa), Northwest (Kebbi), South-West (Oyo). Southeast (Anambra), South-South (Delta) and domesticated strain ubtained from Lagos. The fish were bred in the wet laburatory of the Department of Fish technology Biotechnology of the Institute for Oceanography and Marine Research, Lagos and fed for 12 weeks before stibjected to growth study. The study involved allocation of 25 juveniles of each strain in Im hapas installed in a 0.4 ha at Badore fish farm, Lagos, Nigeria, fed $3 \%$ body weight twice daily while sampling forth-nightly. The results showed that the domesticaled strain of ( gariepimus performed significantly batter $(\alpha \quad 0.05)$ ihan the six wild strains studied. This may be atiributable to selective breeding which probably had been carried out by the farmers from which the broodstocks were purchased and mixture of the gene pool of improved Duich strain commonly cultured. There was however no significant variation in the SGR and FCR among the sirains. However; the growth study showed that the strain from North- West (Kehbi) did not perfurm as much as other strains in terms of these growth indices. However it had the highest survival (96\%). The sirains from Oyo and Anambra however showed better growth over the rest strains from the wild. The implication of the breeding potentials of C. geriepinus strain from Kebbi, Oyo and Anambra is that if several selective breating of these strains are carried out and ihe gene poot of Kehbi is cambined with any of these two, we are likely to abtain fish seed of better growth and strvival.
\end{abstract}

Keywords: (imwth, performance, wild, C. gariepinus.

Introduction

Varias gariepinus is a remarkable fish species in Nigeria where it is the leading aquatic crop. It has the credentials of fast growth, resistance to disease and handling stress. It has air-breathing structure and can therefore tolerate very low oxygen levels in any aquatic environment as well as on land. Nigeria is presently the largest producer of cattish (FAO, 2003).

Growth is a complex process and it can be defined as an increase in size (length, volume, mass and body composition) of an organism over time. Growth can differ between species, strains or populations within the same species and different individuals within the same population. Among cultured animals, fish species exhibit the largest individual variation in growth. For most farmed animals, the coefficient of variation (CV) for growth varies between 7 and $10 \%$. However, for fish species the coefficient of variation is between 20 and $35 \%$ (Gjedrem, 1997). Disparity of individual growth may result from individual differences in feed intake (Umino et al., 1997) or feed efficiency (Qian et al., 2002) or combination of both. More often than not, social hierrhachies have been implicated as the main sourec of growth disparity, resulting in dominant (large individuals) and subordinate (smaller individuals). The dominant individuals often monopolize larger share of available resources, bringing about faster growth of these dominant fish with respect to subordinate oncs. Other environmental factors that may affect size disparity include stock density, temperature, water current daylight and maternal effect (Kestemont et al., 2003), cannibalsm (Baras, 1998) and protein turn-over (Bang et al., 2004). Apart from environmental factors, genetic factors may play a role in bringing about differences in the growth of individual fish (Qian et al., 2002). The study was carried out to evaluate growth performance of wild strains of the catfish ( $C$. gariepinus) from different water bodies in Nigeria. 


\section{Materials and Methods}

The growth studies involved allocation of 25 juveniles each of 6 wild strains and domesticated strain of $C$. gariepinus in $1 \mathrm{~m}^{3}$ hapas installed in a 0.4 ha at Badore fish farm. The fish were fed $3 \%$ body weight twice daily while sampling fortnightly.

- Fxperimental design and collection of Clarias gariepinus strain juveniles: The experiment was designed to investigate the effects of strain variation on growth performance, survival rate, Feed Conversion Ratio and growth pattern. Fish for spawning were collected from 6 states of Nigeria covering the 6 geopolitical zones namely, NorthCentral (Lokoja: N6 $6^{\circ} 49.02^{\prime}, \mathrm{E}^{\circ} 44.1^{\prime}$, Sakin Noma: N8 $8^{\circ} 12.13^{\prime}$ E6 $6^{\circ} 24.2^{\prime}$ ), North-Fasl ( Kiri lake: N09 $61.2^{\prime}$ L12 28.5', Gerio lake: N09 $12.8^{\circ} \mathrm{E} 12^{\circ} 28.6^{\prime}$, North-West (Argungun: N $12^{\circ} 44.6^{\prime}$; L004 $31.31^{\prime}$, River Niger :

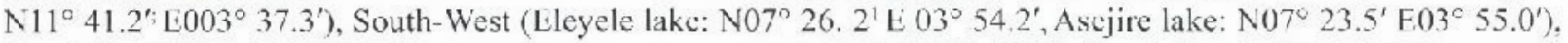
South-East (Otuocha: N06 20.2' $006^{\circ} 50.3^{\prime}$, Igbariam: N06 23.5'006 56.3'), South-South (Umuochi/Ona river: N06 $16.1^{\prime}$ E06 42.5', River Ethiope: N05 54.4' E05 40.4') and domesticated strain obtained from Lagos. These were conditioned, fed and bred in the wet laboratory of the Nigerian Institute for Oceanography and Marine Research, Victoria Island, I agos and reared to average weight of $2244 \mathrm{~g}$.

- Feeding and feed supplements: The experimental fish were fed wice a day at 10:00 and 17:00 hours with the feed produced by coppens feed from Netherlands while the daily surface water temperature was measured. The feeding rate was $3 \%$ of the body weight of the fish per day throughout the experiment. The amount of the feed was adjusted once in two weeks based on the body weight of the fish.

- Data collection: During the experiment, water quality parameters such as temperature, dissolved oxygen (DO) concentration and pII were measured daily. 'Total dissolved solid particles (TDS), conductivity and salinity were also measured once in two weeks interval with the same instrument.

- Sampling of fish and measuring of growth parameters: $50 \%$ of fish were sampled every two wecks for their body weight and body length measurement. Length and weight of the fish were measured using ruler and digital weight balance (Ohaus portable balance), respectively. Mortality of the fish was also registered throughout the experiment.

- Data analysis: Based on the data collected during the experiment, growth performance and feed conversion ratio and rate of survival were calculated as follows:

SGR $(\% ;$ day $)=\{(\operatorname{lnFMBW} \quad-\quad \operatorname{InIMBW}) ; \mathrm{d}\} \quad 100$
$\mathrm{FCR}=\mathrm{FI}(\mathrm{g}) / \mathrm{MBWG}(\mathrm{g})$
Survival rate $(\%)=(\mathrm{NSF}-\mathrm{NDF} / \mathrm{NSF}) \times 100$

Where: FBW and IBW are the final and initial mean body weight respectively, $\mathrm{d}$ is the time interval in days during the study period, FI is amount of feed intake (g). MBWG is mean body weight gain in gram (g). - NSF and NDF are Number of stocked and dead fish during, respectively.

Results:

Table 1: Growth performance of Clarias gariepinus fingerlings reared over 10 weeks in hapa.

\begin{tabular}{|c|c|c|c|c|c|c|c|}
\hline & $\begin{array}{c}\mathrm{NW} \\
\text { (Kebbi) }\end{array}$ & $\begin{array}{c}\mathrm{NE} \\
\text { (Adamawa) }\end{array}$ & $\begin{array}{c}\text { NC } \\
\text { (Kogi) }\end{array}$ & $\begin{array}{l}\text { SW } \\
\text { (Oyo) }\end{array}$ & $\begin{array}{c}\text { SE } \\
\text { (Anambra) }\end{array}$ & $\begin{array}{c}\text { SS } \\
\text { (Delta) }\end{array}$ & Dom. \\
\hline Initial weight (g) & $26.0 \pm 4.1$ & $42 \pm 4.3$ & $22.0 \pm 3.9$ & $43.3 \pm 5.6$ & $32.1 \pm 2.6$ & $22.0 \pm 3.6$ & $32.1 \pm 3.5$ \\
\hline Final weight (g) & $129.8 \pm 24.6$ & $185.8 \pm 14.4$ & $161.8 \pm 9.6$ & $204.7 \pm 4.8$ & $196.1 \pm 18.9$ & $150.2 \pm 16.2$ & $240.0 \pm 14.6$ \\
\hline Weight gain (g) & $103.8 \pm 21.6$ & $143.1 \pm 13.8$ & $139.8 \pm 3.9$ & $161.4 \pm 4.3$ & $164.0 \pm 14.6$ & $128.2 \pm 15.8$ & $207.9 \pm 13.6$ \\
\hline Weight gain (\%) & 399.2 & 393.6 & 635.1 & 372.7 & 523.1 & 582.7 & 647.7 \\
\hline Av. daily gain(g/fish) & 1.482 & 2.40 & 1.20 & 2.31 & 2.40 & 1.83 & 2.97 \\
\hline FCA & 1.74 & 1.91 & 1.70 & 1.62 & 1.61 & 1.65 & 1.36 \\
\hline SGR (\%/day) & 1.0 & 0.99 & 1.11 & 0.96 & 1.15 & 1.19 & 1.21 \\
\hline Survival & 96 & 88 & 76 & 80 & 86 & 76 & 70 \\
\hline
\end{tabular}

ANOVA $(\alpha=0.05)$ revealed significant variation in the percentage weight gain, average daily weight gain, average daily growth and survival of fingerlings of the wild strain from the six geopolitical zones. The domesticated strain of $C$. gariepinus performed much better than the six wild strains studied. This may be attributable to selective breeding which probably had been carried out by the farmers from which the broodstocks were purchased. It could equally be due to the use of the Dutch strain which is known to have superior growth over the traditional strain found in Nigeria There was however no significant variation in the SGR and FCR among the strains. The growth study showed that the strain from North- West (Kebbi) did not perform as much as other wild strains in lerms of these growth indices. However it had the highest survival ( $96 \%)$.

\section{Discussion}

There were variations in the growth performance both within and between strains of Clarias gariepinus studied. This is in agreement with the finding of Van der Waal (1998) who reported that African cattish exhibits considerable growth variation 
both under aquaculture and in the wild. The causes of such variation are still not clear. Ilowever, it has been suggested that inherent differences genetic makeup and feeding behaviour may contribute to this variation (Valente ct al., 2001; Sundström et al, 2003; Martins ct al., 2005). The ability of an organism to utilize nutrients especially protein will positively influence its growth rate (Sogbesan and Ugwumba, 2008). Optimal water quality was maintained by frequently changing the water through the flow-through system. This also ensured that metabolic wastes did not accumulate in the facility. At the end of the experiment, there were significant differences in growth performance and nutrient utilization between the 6 strains and control (domesticated strain). The domesticated strain performed much better than all the wild strains. This was in agreement with Dunham et al. (2001) who reported that domesticated strains usually perform better in the aquaculture enviromment than wild strains probably due to the effect of inbreeding brought about by repeated use of tish of the same lineage. The author further maintained that reliance on wild broodstock is risky and negates the opportunity to enhance disease resistance (as well as other production traits) through selective breeding. The detrimental effects of inbreeding are well documented and can result in decreases of 30 percent or greater in growth production, survival and reproduction in some cases, the author reported. Wild strains of good spawning performance could however be selected for breeding programs. Dunham et al. (2001) reported that good broodstock management needs to be promoted to avoid inbreeding problems.

Another possibility of better growth observed in the domesticated strain is that most of the C. gariepinus in Nigeria farms are either exotic strain or a mixture of the genome of traditional strain with the exotic strain. The exotic C. gariepinus is marketed in Nigeria under different names: Fxotic C. gariepinus, albino Clarias, Holland or Dutch Clarias and it constitutes one of the major strains of the large African cattish cultivated (Oycleye and Omitogun, 2007). C. gariepinus was thought to be the progenitor of exotic C gariepinus (Dada and Wonah, 2003), which has undergone many years of selection and domestication (Cambray and Van Der Waal, 2006).

\section{Conclusion}

One of the problems associated with aquaculture development in Nigeria is that native species have not been selected and domesticated enough to be acclimated and suitable for rearing conditions. Thus, response to management is limited. High growth rate $(6 \%)$ in the catfish Ictalurus punctatus from generalion to generation was attributed to long period of domestication and adaptation to rearing condition (Dunham el al., 2001). This study therefore has important implication for Clurias gariepinus culture in Nigeria.

\section{REFERENCES}

Bang, A., Gronkjar, P. and Malte, II.(2004). Individual variation in the rate of oxygen consumption by Zebrafish embryos. Journal of Fish Biolngy, 64: $1285-1296$.

Baras, E. (1998). Bases biolngiques du cannibalisme ez- les poisons. Cah. Ethioi., 18: 53-98.

FAO (2003). Aquaculture production. Yearbook Fisheries Stutistics. 96/2, FAO, Rome.

Gjedren, T. (1997). Contribution for selective breeding to future aquaculture development. Journal of World Aquaculture Society, 3, 3345.

Kestemont, P., Jourdan, S., Harbert, M., Melard, C., Paspatis, M., Fontaine, P., Cuvier, A., Kantouri, M. and Baras, E. (2003). Size beterogeneity, cannibalism and competition in cultured predatory fish larvae: Bivlic and Abiotic influences. Aquaculture, 227, 333-356

Martins-Smith, K. and Armstrong, J. (2002). Growth rate of wild stream-dwelling Atlantic salmon correlate with activity and sex but not dominance. Journal of Ecolngy, 71, 413-423.

Martins, C.I., Schrama, J.W. and Verreth, J.A. (2005). Inherent variation iı growth efficiency of African catfish Clarias gariepinus (Burchell 1822) juveniles. Aquac. Res., 36: 868-875.

Oyeleye, O.O and Omitogun, O.G. (2007). Evaluation of motility of the short-term cryo preserved sperm of African giant catfish (Clarizs gariepinus). Ife. Jousnal of Agricuiture, Vol. 22(1): 11-16.

Qian, X, Cui, Y, Xie, W., Xiong, B. and Yang, Y. (2002). Individual variations in growth, food intake and activity in juveniles Chinese sturgear (Acipenser sinensis). Coray journal of Applied ichthyology, 18: 695-698.

Sogbesan, A.O. and Ugwumba, A.A.A. (2008). Nutritional cvaluation of termite Macrolermes subhyalinus. Meal as animal protein supplements in the diets of Heterobranchus longifilis fingerlings. Turk. J. Fish. Aqua, Sci, 8: 149-157.

Sundström, L.F., Devlin, R.II., Johnsson, J.I. and Biagi, C.A. (2003). Vertical position refleets incrcased feeding behaviour in grow th hormone transgenic coho salmon (Oncorhynchus kisuich). Ethol., 109: 701-712.

Umino, T., Arai, K. and Nakgawa, H. (1997). Growth performance in clonal crucian carp (Carassus langsdorfii), Effect of genetic difference and feeding History. Aquaculture, 155: 271-283.

Van der Waal, B.C.W. (1998). Survival strategies of sharptooth catfish Clarias gariepinus in desiccating pans in the northern Kruger National Park, Koedoe. African Protected Area Conservation and Science', 41: 131-138.

Valente, L.M.P., Saglio, P., Cunha, L.M. and Faucomneau, B. (2001). Feeding behaviour of fast- and slow-growing strains of rainbow trout, Oncorhynchus mykiss during first feeding. Aquac. Res., 32: 471- 480. 